\title{
Kecemasan Pedagang Unggas Tentang Wabah Penyakit Flu Burung Di Pasar Tunggorono Jombang
}

\author{
Kurniawati \\ Prodi D3 Keperawatan FIK UNIPDU Jombang \\ Email: nia_du@yahoo.co.id
}

\begin{abstract}
Avian influenza is one of an infectious disease caused by influenza virus is transmitted by Avian influenza humans. This incident resulted in anxiety for the chicken market traders in tunggorono Jombang. Levels of anxiety can be clarified into 5 levels ie no anxiety, mild anxiety, worry is, severe anxiety, and anxiety heavy (panic).The purpose of this study to describe the anxiety level of poultry traders in the market Tunggorono Jombang. The study design is descriptive. Respondents who studied the poultry traders in the market Tunggorono Jombang. Sampling with a total sampling technique, a large sample of 30 respondents. Methods of observation and data collection by questionnaire. Analyze data using descriptive analysis formula is a frequency distribution. The result showed that the level of axienty in the market Tunggorono poultry traders as much as $53,4 \%$ in the level of anxiety being.Anxiety levels of poultry traders about avian influenza outbreak in Jombang Tunggorono market is the level of anxiety is. This needs to be done counseling or health education to lower levels of anxiety.
\end{abstract}

Key words : Anxiety, Avian influenza

\section{Pendahuluan}

Flu burung merupakan salah satu penyakit menular yang disebabkan oleh virus influenza yang ditularkan oleh unggas yang dapat menyerang manusia. (Dep.kes. RI. 2005). Pada tahun 2005 penyakit ini dinyatakan sebagai masalah internasional yang memerlukan perhatian khusus seperti halnya penyakit menular lainnya seperti HIV/AIDS. (WHO, 2005). Hingga sampai tanggal 6 Februari 2004, didapatkan 20 orang terserang flu burung. Beberapa bulan yang lalu tepatnya pada bulan pertengahan desember 2011 terjadi kematian unggas secara misterius yang kabarnya berasal dari pedagang yang menjual di pasar tunggorono, sebanyak 10 laporan yang diterima petugas pasar tentang kejadian kematian unggas secara misterius, hal ini diutarakan pada saat studi kasus yang dilakukan peneliti bersumber dari Kepala Dinas Pasar Tunggorono. Kejadian ini menimbulkan kecemasan dan ketakutan dimana-mana. Salah satunya adalah para pedagang unggas di Pasar Tunggorono Jombang.
Mereka juga mengalami kecemasan akibat penyebaran wabah penyakit flu burung. Hal ini kemungkinan disebabkan oleh banyaknya unggas mati yang kemungkinan telah terserang penyakit flu burung.

Faktor yang mempengaruhi kecemasan para pedagang unggas adalah mereka takut tertular penyakit ini jika penyakit ini mewabah diwilayah mereka, para pedagang juga khawatir akan mengalami kerugian karena penghasilannya mengalami penurunan hingga gulung tikar. Upaya pencegahan penularan tentu saja dilakukan dengan cara menghindarkan bahan yang berhubungan dengan unggas, gunakan pelindung jika bersentuhan dengan unggas, desinfeksi alat-alat yang berhubungan dengan unggas, mengkonsumsi daging unggas yang benarbenar sudah masak, serta memberikan penyuluhan kepada semua warga untuk meyakinkan bahwa virus tersebut dapat dihindari dan di berantas. Namun kecemasan itu tampaknya masih 
menghantui para peternak maupun para pedagang unggas. Penelitian ini bertujuan untuk mengidentifikasi Gambaran Kecemasan Pedagang Unggas Terhadap Wabah Penyakit Flu Burung di Pasar Tunggorono Jombang.

\section{Metode Penelitian}

Desain penelitian yang digunakan dalam penelitian ini adalah deskriptif. Tempat dan waktu penelitian dilakukan di Pasar Tunggorono Jombang pada tanggal 5 Januari 2012. Populasi yang dipakai dalam penelitian ini adalah pedagang unggas di Pasar Tunggorono Jombang sejumlah 43 orang. Sample yang digunakan dalam penelitian ini adalah sebanyak 30 orang pedagang unggas di Pasar Tunggorono Jombang. Dalam penelitian ini sampling yang digunakan adalah purposive sampling yaitu teknik penetapan sampel di antara populasi sesuai dengan yang dikehendaki peneliti, sehingga sampel tersebut dapat mewakili karakteristik populasi yang telah dikenal sebelumnya. Dalam penelitian deskriptif variable yang digunakan variable tunggal, yaitu tingkat kecemasan para pedagang unggas.

Peneliti menggunakan observasi dengan check list yaitu suatu pengecekan berisi nama subyek dan beberapa gejala/ atau identitas lainnya dari sasaran pengamatan, pengamat memberi tanda check $(\sqrt{ })$ pada daftar tersebut yang menunjukkan gejala atau arti dari sasaran pengamat.

Peneliti mengadakan pendekatan kepada pedagang unggas untuk mendapatkan persetujuan sebagai responden. Data dikumpulkan melalui observasi sebagai subyek penelitian yaitu para pedagang unggas Pasar Tunggorono Jombang. Setelah data terkumpul dilakukan pengecekan terhadap observasi yang telah dilakukan. Kemudian dilakukan penilaian dengan teori HARS.

\section{Hasil dan Pembahasan}

Hasil Penelitian

Data Umum

Data ini menggambarkan karateristik berdasarkan umur, jenis kelamin dan pendidikan yang terjadi pada responden.

Karakteristik Responden Berdasarkan Umur Responden

Tabel 1 Distribusi Frekuensi Responden Berdasarkan Umur di Pasar Tunggorono Jombang 2012

\begin{tabular}{lccc}
\hline No & Umur & $\begin{array}{c}\text { Jumlah } \\
\text { Responden } \\
\text { (orang) }\end{array}$ & Prosentase (\%) \\
\hline 1 & $25-34$ & 8 & 26,6 \\
2 & $35-44$ & 13 & 43,3 \\
3 & $45-54$ & 9 & 30,1 \\
\hline \multicolumn{2}{l}{ Total } & 30 & 100 \\
\hline
\end{tabular}

Sumber kuesioner

Dari tabel di atas di dapatkan jumlah responden hampir separuhnya yaitu berumur 35-44 tahun hampir setengahnya sebanyak 13 responden (43,3\%). 45-54 tahun hampir setengahnya sebanyak 9 responden $(30,1 \%)$. Dan 25-34 tahun hamper setengahnya sebanyak 8 responden $(26,6 \%)$.

Karakteristik Responden Berdasarkan Janis Kelamin

Tabel 2 Distribusi Frekuensi Responden Berdasarkan Janis Kelamin di Pasar Tunggorono Jombang 2012.

\begin{tabular}{llcc}
\hline No & Jenis Kelamin & $\begin{array}{c}\text { Jumlah } \\
\text { Responden } \\
\text { (orang) }\end{array}$ & $\begin{array}{c}\text { Prosentase } \\
(\%)\end{array}$ \\
\hline 1 & Perempuan & 5 & 16,7 \\
2 & Laki-laki & 25 & 83,3 \\
\hline Total & 30 & 100 \\
\hline
\end{tabular}

Dari tabel di atas di bahwa hampir seluruhnya berjenis kelamin perempuan sebanyak 25 responden $(16,7 \%)$ dan sebagian kecil berjenis kelamin perempuan sebanyak 5 responden $(16,7 \%)$. 
Karakteristik Responden Berdasarkan Janis Kelamin

Tabel 3 Distribusi Frekuensi Responden Berdasarkan Tingkat Pendidikan di Pasar Tunggorono Jombang

\begin{tabular}{llcc}
\hline No & Pendidikan & $\begin{array}{c}\text { Jumlah } \\
\text { Responden } \\
\text { (orang) }\end{array}$ & $\begin{array}{c}\text { Prosentase } \\
(\%)\end{array}$ \\
\hline 1 & SD/Sederajat & 5 & 16,7 \\
2 & SLTP/Sederajat & 9 & 30 \\
3 & SMU/Sederajat & 16 & 53,3 \\
\hline \multicolumn{2}{l}{ Total } & 30 & 100 \\
\hline
\end{tabular}

Dari tabel di atas dapat diketahui bahwa sebagian besar dari pendidikan responden adalah SMU/sederajat sebanyak 16 responden $(53,3 \%)$, SLTP/Sederajat hampir setengahnya sebanyak 9 responden (30\%), dan $\mathrm{SD} /$ Sederajat sebagian kecil sebanyak 5 responden $(16,7 \%)$.

\section{Data Khusus}

Berikut hasil penelitian di Pasar Tunggorono Jombang pada pedagang unggas yang $100 \%$ mengalami kecemasan serta tingkat kecemasannya menurut HARS.

Karakteristik Responden Berdasarkan Tingkat Kecemasan.

Tabel 4 Distribusi Frekuensi Responden Berdasarkan Tingkat Kecemasan di Pasar Tunggorono Jombang.

\begin{tabular}{llcc}
\hline No & Kriteria & $\begin{array}{c}\text { Jumlah } \\
\text { Responden } \\
\text { (orang) }\end{array}$ & $\begin{array}{c}\text { Prosentase } \\
(\%)\end{array}$ \\
\hline 1 & Cemas Ringan & 14 & 46,6 \\
2 & Cemas Sedang & 16 & 53,4 \\
3 & Cemas Berat & 0 & 0 \\
\hline \multicolumn{2}{l}{ Total } & 30 & 100 \\
\hline
\end{tabular}

Dari tabel di atas didapatkan bahwa sebagian besar masuk dalam kategori cemas sedang sebanyak 16 responden $(53,4 \%)$, dan hampir setengah masuk dalam kategori cemas ringan sebanyak 14 responden $(46,6 \%)$

\section{Pembahasan}

Sebagaimana yang telah ditegaskan dalam metode penelitian ini jenis penelitian yang digunakan adalah diskriptif yang berarti menggambarkan suatu variable, gejala, atau keadaan dan tidak bermaksud untuk menguji hipotesis tertentu dimana peneliti ingin mengetahui gambaran kecemasan pedagang unggas tentang wabah penyakit flu burung.

Setelah dilakukan penelitian di Pasar Tunggorono Jombang didapatkan pedagang unggas mengalami cemas sedang sebanyak 16 responden $(53,4 \%)$ seperti jantung berdebar-debar, wajah merah padam, sulit bernafas, merasa pusing, mual, tidak dapat mengendalikan diri. Berdasarkan prilaku bicara banyak dan lebih cepat, susah tidur dan perasaan tidak nyaman. (Netty Herawati, 1997). Tingkat kecemasan seseorang dapat dilihat dari tanda-tanda fisik maupun perilaku, maka disini peneliti meneliti tingkat kecemasan dengan skala HARS yang memeliki gejala dan tanda yang ada pada responden dan didapatkan sebagian besar responden dengan kecemasan sedang yang kemungkinan dipengaruhi oleh : Umur responden, seperti pada table 1 didapatkan jumlah responden hampir separuhnya yaitu berumur 35-44 tahun hampir setengahnya sebanyak 13 responden $(43,3 \%)$. 45-54 tahun hampir setengahnya sebanyak 9 responden $(30,1 \%)$. dan 25-34 tahun hampir setengahnya sebanyak 8 responden $(26,6 \%)$, semakin cukup umur tingkat kematangan dan kakuatan seseorang akan lebih matang dalam berfikir dan bekerja, hal ini sebagai akibat dari pengalaman dan kematangan jiwanya. (Hurlock, 1998). Disini sebagian besar umur responden adalah 35-44 tahun, umur tersebut adalah termasuk yang dimana tingkat kematangan dan kekuatan seseorang akan lebih matang dalam berfikir dan bertindak sehingga faktor umur juga dapat mempengaruhi kecemasan karena sebagian besar responden dengan tingkat kecemasan sedang.

Tingkat pendidikan, dimana pada table 3 dapat diketahui bahwa sebagian besar dari pendidikan responden adalah 
SMU/sederajat sebanyak 16 responden $(53,3 \%)$, SLTP/Sederajat hampir setengahnya sebanyak 9 responden $(30 \%)$, dan SD/Sederajat sebagian kecil sebanyak 5 responden $(16,7 \%)$. Semakin tinggi tingkat pendidikan seseorang semakin mudah menerima informasi sehingga banyak pola pengetahuan yang dimiliki. Sebaliknya pendidikan yang kurang akan menghambat perkembangan sikap seseorang terhadap nilai-nilai yang baru diperkenalkan (Kuncoroningrat). Dari pendidikan responden yang setingkat SMU/sederajat tersebut, informasi yang masuk akan lebih mudah diterima dan ilmu yang diperoleh akan lebih banyak maka dapat meningkatkan mekanisme koping terhadap kecemasan sehingga tidak terjadi kecemasan yang lebih berat.

Hal ini sesuai dengan umur dan tingkat pendidikan responden yang mana umur sudah lebih matang, sedangkan dari pendidikan responden sebagian besar responden lebih mudah dalam menerima informasi maka benar bahwa kecemasan seseorang dapat dilihat dari tanda dan gejala yang dialami seseorang.

\section{Kesimpulan}

Setelah dilakukan penelitian pada tanggal 5 Januari 2012 berdasarkan HARS ternyata pada pedagang unggas sebagian besar masuk dalam kategori cemas sedang sebanyak 16 responden $(53,4 \%)$.

\section{Saran}

1. Bagi Profesi Keperawatan

Profesi perawat yang berfungsi sebagai fasilitator hendaknya dapat memberikan wawasan pada pasien atau masyarakat pada umumnya dan khusunya pada pedagang unggas, tentang tanda dan gejala serta dampaknya penyakit flu burung sehingga dapat menyesuaikan diri sehingga tidak mengalami.

2. Bagi Profesi Selanjutnya

Diharapkan penelitian tentang flu burung ini dapat dikembangkan dengan menggunakan literatur yang lebih banyak dengan metode lebih baik sehingga dapat menggambarkan kecemasan.

3. Bagi Responden

Diharapkan dari hasil penelitian sebagai sarana informasi dan pengetahuan bagi responden untuk meningkatkan mekanisme koping dalam mengurangi kecemasan yang dialami.

\section{Daftar Pustaka}

Atmawinata, Edi (2006). Kiat Bebas Flu Burung. Bandung: Yrama Widya

Cucunawangsih. (2006). Flu Burung Cara Mewaspadai dan Mencegahnya perawatan. Jakarta Bhuana Ilu Populer

Hawari, Dadang. 2004. Managemen Stress,Cemas dan Depresi. . Jakarta : FKUI

Herawati, Netty. 1993. Asuhan Keperawatan Klien Ansietas. Jakarta : FKUI

Nursalam. (2003). Konsep dan Penerapan Metode Penelitian Ilmu Keperawatan. Jakarta : Agung Seto.

Sugiono. 2005. Metode Penelitian Administrasi. Bandung : Alfa Beta

Stuart, Gail Wiscare dan Sandra J. Sundeen. 1998 . Buku Saku Keperawatan Jiwa. Edisi 3. Jakarta : EGC

Tomb, David A. 2003. Buku Saku Psikiatri. Edisi 6. Jakarta : EGC

Tundsend, Mary C. 1999. Diagnosa Keperawatan Pada perawatan psikiatri.

Jakarta : EGC.

Pardi (2012).Pusat informasi infeksistandart prosuder 2005-avian flu. http//:Infeksi.com.tanggal 11 Januari 2012. Jam 12.12.

Wardi (2012).Wabah flu burung wabah perekonomian.http//: Suara karya.com. Tanggal 11 Januari 2012. Jam 12.20 